\title{
Implementasi Algoritma $Q$ Learning Pada Robot Line Follower
}

\author{
Irvan Pramana ${ }^{1}$, dan Asrizal Deri Futra ${ }^{1 *}$ \\ ${ }^{1}$ Politeknik Negeri Batam, Batam, Indonesia
}

*Email: deri@polibatam.ac.id

\begin{abstract}
Penggunaan metode algoritma $Q$ learning pada robot mampu melakukan perbaikan tanpa harus memperbaharui aturan dari luar karena sifatnya off policy (dapat mengikuti aturan apapun untuk menghasilkan solusi optimal). Dalam sistem kerjanya, robot melakukan proses pembelajaran terhadap garis lintasan yang dilaluinya sehingga didapatkan suatu nilai untuk aksi yang telah dilakukan pada setiap state yang terdeteksi. Tujuan penelitian ini adalah membuat robot bergerak berdasarkan nilai $Q$ function tertinggi yang dihasilkan oleh algoritma $Q$ learning. Berdasarkan hasil pada pengujian penerapan algoritma $Q$ learning pada robot line follower, persentase keberhasilan yang didapatkan adalah sebesar $100 \%$ untuk percobaan pertama, $66,67 \%$ untuk percobaan kedua, $100 \%$ untuk percobaan ketiga, $66,67 \%$ untuk percobaan keempat, dan $100 \%$ untuk percobaan kelima sehingga rata - rata keberhasilan sebesar $86,67 \%$.
\end{abstract}

Kata kunci: Robot line follower, $Q$ function, $Q$ learning

\section{Pendahuluan}

PERKEMBANGAN teknologi telah banyak mengalami kemajuan dari masa ke masa terutama dalam dunia robotika. Kecerdasaan buatan atau AI (Artificial Intelligence) memegang peran penting dalam perkembangan dunia robotika karena memungkinkan sebuah robot dapat bergerak secara otomatis hanya dengan memasukkan perintah sederhana. Salah satu jenis robot yang umum dijumpai adalah robot line follower. Robot line follower merupakan sebuah robot yang dapat mengikuti garis secara otomatis dengan program yang telah didefinisikan terlebih dahulu.

A.S. Romadhon dan M. Fuad melakukan penelitian mengenai robot line follower. Pada penelitian tersebut, peneliti membuat perancangan sistem kontrol gerak menggunakan kontrol PID untuk menyelesaikan masalah bagaimana sebuah robot line tracer dapat melakukan kontrol gerak pada bidang datar berwarna putih dengan garis berwarna hitam dalam lingkungan statis, sehingga robot dapat mengikuti garis hitam tersebut. Robot dapat berjalan dengan baik pada lintasan lurus dan lengkung saat kondisi cahaya terang [1]. Selanjutnya, David melakukan penelitian dengan mengimplementasikan kendali logika fuzzy untuk pengaturan pergerakan motor supaya robot mengikuti jalur yang telah ditentukan [2]. A. Wajiansyah, dkk melakukan penelitian robot line follower dengan menggunakan fuzzy logic. Hail penelitian menunjukkan bahwa robot dapat mengikuti garis [3]. Made Santo G, dkk melakukan penelitian pada sistem navigasi robot otonom beroda dalam medan yang tidak terstruktur dengan sistem kendali BehaviorBased Robot [4]. V. R. Cruz-Álvarez, dkk melakukan penelitian mengenai robot follower menggunakan Lego Mindstorms Kit dan Q Learning [5]. S. Arifin dkk melakukan penelitian mengenai peggunaan metode $\mathrm{Q}$ learning untuk pencarian rute line follower mobile robot pada maze [6].

Pada penelitian ini, algoritma $Q$ learning diimplementasikan pada robot line follower di mana robot dapat melakukan pemilihan aksi dengan nilai yang optimal berdasarkan nilai $Q$ function yang dihasilkan oleh algoritma $Q$ learning tanpa diperlukannya pembaharuan aturan dari luar.

\section{METODE}

\section{A. Perancangan dan Perakitan Perangkat Keras}

Pada perancangan perangkat keras, diperlukan beberapa komponen yaitu 6 buah sensor obstacle sebagai pendeteksi garis lintasan, 1 buah Arduino ATMega 2560 sebagai mikrokontroler, 1 buah driver motor L298N sebagai pengatur kecepatan dan arah putaran motor, 2 buah roda plastik sebagai roda robot, 2 buah motor DC sebagai penggerak roda plastik, 1 buah Micro SD card module sebagai penghubung antara Arduino dengan $S D$ card, 1 buah $S D$ Card untuk menyimpan data penelitian, 1 buah Converter Module 5V DC sebagai pengubah tegangan menjadi 5V DC, 1 buah Bluetooth Module HC-05 sebagai serial komunikasi antara mikrokontroler dengan aplikasi Arduino, 1 buah Baterai Lipo 2 Cell sebagai sumber tegangan, dan kabel jumper secukupnya. Selanjutnya komponen tersebut dirakit mengikuti blok diagram pada gambar 1. Dari gambar 1, power supply akan menyuplai tegangan sebesar $\pm 7,4$ VDC pada 3 buah komponen yaitu converter module 5VDC, Arduino ATMega 2560, dan driver motor L298N. Pada converter module 5 VDC terjadi penurunan tegangan dari tegangan sumber $\pm 7,4$ VDC menjadi 5 VDC. Tegangan ini digunakan sebagai tegangan input dari sensor $I R$ obstacle. Sedangkan pada Arduino ATMega 2560 dan driver motor L298N, tegangan dari power supply digunakan sebagai tegangan kerja untuk menghidupkan kedua komponen tersebut. Setelah komponen ini aktif dan bekerja, selanjutnya akan terjadi sebuah proses sistem kerja dari perangkat keras. Pertama kali 
sensor IR obstacle akan mendeteksi garis, selanjutnya hasil pendeteksian akan diproses di dalam Arduino ATMega 2560 dengan algoritma $Q$ learning. Hasil dari proses akan dilanjutkan ke 3 buah komponen yaitu Micro SD card module, Bluetooth Module HC-05, dan driver motor L298N. Pada bagian Micro SD card module, data hasil pemrosesan akan disimpan pada sebuah SD card. Pada bagian Bluetooth Module HC-05, data akan diteruskan pada serial monitor di PC. Sedangkan pada driver motor L298N, hasil proses data akan diubah menjadi sebuah gerakan pada motor DC.

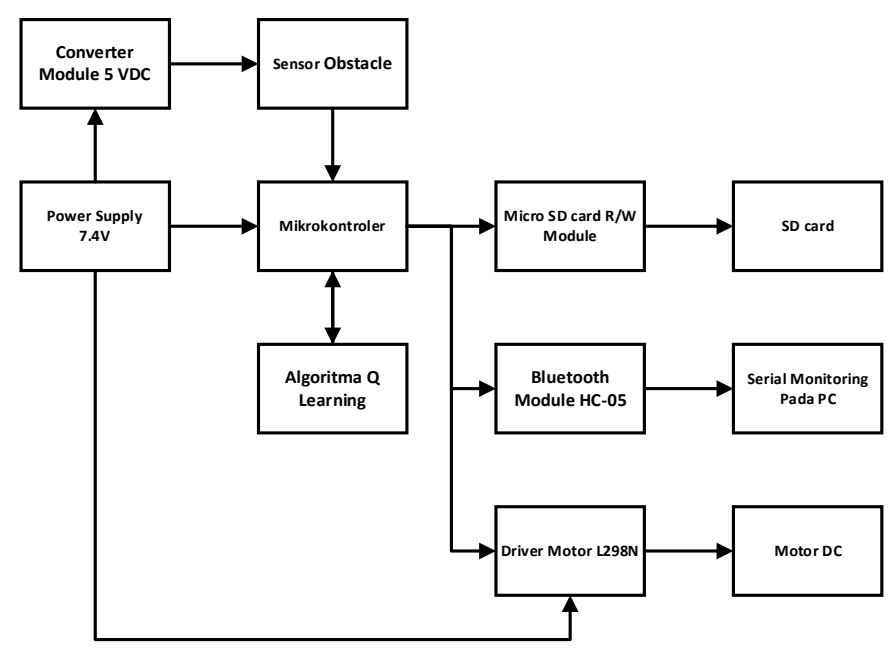

Gambar 1. Blok diagram sistem kerja perangkat keras

Gambar 2 merupakan tampilan robot ketika semua komponen selesai dirakit.

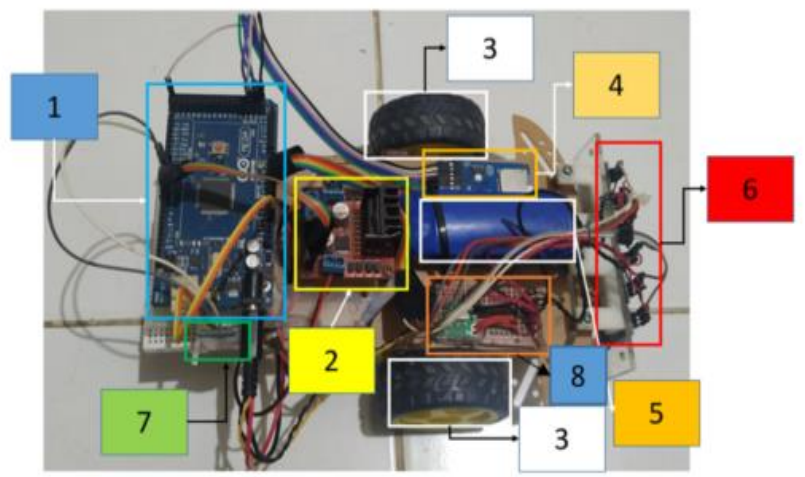

Keterangan:

1. Arduino ATMega 2560.

2. Driver Motor L298N.

3. Motor DC + Roda Plastik.

4. Micro SD Card + SD Card .

5. Baterai Lipo 2 Cell.

6. Sensor Obstacle.

7. Bluetooth Module HC-05

8. Converter Module 5V DC.

Gambar 2. Robot line follower dan keterangan komponen

\section{B. Perancangan Lintasan}

Lintasan dirancang menyerupai angka 8 (delapan) dengan warna hitam pada bagian garisnya dan warna putih untuk background lintasan. Pemilihan warna ini disebabkan kedua warna ini memiliki warna yang kontras sehingga nilai dari hasil pembacaan memiliki nilai yang kontras antara satu dengan yang lainnya sehingga memudahkan robot dalam mendeteksi garis lintasan.

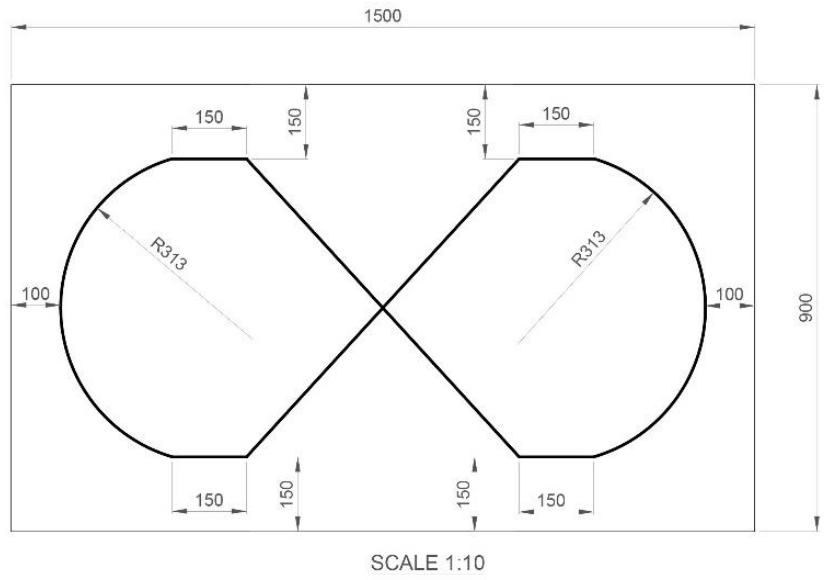

Gambar 3. Desain Lintasan

Gambar 3 merupakan desain lintasan dengan dimensi dalam satuan mm dan skala yang digunakan adalah 1:10. Lintasan ini memiliki panjang $150 \mathrm{~cm}$ dan lebar $90 \mathrm{~cm}$. Jarak antara tepi lintasan dengan tepi garis hitam untuk sisi kiri kanan sebesar 10 $\mathrm{cm}$ sedangkan atas dan bawah sebesar $15 \mathrm{~cm}$. Untuk lebar garis warna hitam memiliki nilai $3 \mathrm{~cm}$ dikarenakan lebar ideal untuk 2 buah sensor yang terletak ditengah yaitu $3 \mathrm{~cm}$.

\section{Perancangan Perangkat Lunak}

Dalam perancangan perangkat lunak ini dibagi menjadi 3 bagian yaitu fase learning, penyimpanan nilai $Q$ function, dan pengambilan aksi berdasarkan nilai maksimum $Q$ function.

a. Fase Learning

Fase learning adalah proses pembelajaran robot terhadap lingkungan yang memiliki tujuan mendapatkan nilai $Q$ function pada masing - masing keadaan (state) yang terdeteksi di setiap aksi yang diambil. Terdapat 3 komponen yang diperlukan di dalam fase learning yaitu penentuan banyaknya jumlah state, penentuan banyaknya jumlah aksi, dan penentuan besaran reward. Komponen pertama adalah penentuan jumlah state yang didapatkan dari banyaknya sensor yang digunakan sehingga didapat persamaan (1).

$$
\text { Jumlah state }=2^{n}
$$

Nilai 2 merupakan jumlah keadaan sensor saat mendeteksi garis yaitu ON atau OFF. Sedangkan $n$ adalah banyaknya sensor yang digunakan. Sehingga $2^{6}$ sama dengan 64 . Dikarenakan perhitungan state dimulai dari angka 0 maka jumlah maksimum state berubah menjadi 63. Pada masing masing sensor memiiki nilainya sendiri saat berhasil mendeteksi garis yang ditunjukan pada tabel I. 
TABEL I

NiLAI SETIAP SENSOR

\begin{tabular}{lllllll}
\hline \hline Sensor & S1 & S2 & S3 & S4 & S5 & S6 \\
\hline Nilai & 1 & 2 & 4 & 8 & 16 & 32 \\
\hline \hline
\end{tabular}

Nilai pada tabel I terbentuk berdasarkan pendekatan nilai bit saat sensor aktif atau ON, di mana S1 merupakan bit $0, \mathrm{~S} 2$ adalah bit $1, \mathrm{~S} 3$ adalah bit $2, \mathrm{~S} 4$ adalah bit $3, \mathrm{~S} 5$ adalah bit 4 , dan S6 adalah bit 5. State didapat dari hasil akumulasi dari nilai pada tabel 1 saat mendeteksi garis lintasan.

Komponen kedua adalah penentuan banyaknya jumlah aksi ditentukan oleh user di mana terdapat 5 buah aksi yang digunakan seperti pada tabel II.

\begin{tabular}{cl}
\multicolumn{2}{c}{ TABEL II } \\
AKSI ROBOT \\
\hline \hline Indeks Aksi & Keterangan \\
\hline 0 & Berhenti \\
1 & Belok kiri \\
2 & Maju \\
3 & Belok Kanan \\
4 & Mundur \\
\hline \hline
\end{tabular}

Dalam bergerak, robot hanya akan mengambil aksi belok kiri, maju, dan belok kanan saat berada dalam kondisi ideal. Kondisi ideal yang dimaksud adalah kondisi di mana robot masih berada atau masih mendeteksi garis lintasan. Aksi berhenti digunakan untuk jeda antara aksi dengan durasi 2700 ms. Penggunaan jeda sebesar $2700 \mathrm{~ms}$ bertujuan untuk meminimalisir gangguan pembacaan sensor akibat getaran yang ditimbulkan saat robot melakukan aksi. Sedangkan aksi mundur digunakan saat robot berada di luar garis lintasan.

Untuk kecepatan motor pada masing - masing aksi, digunakan sebuah cara dengan memberikan nilai PWM tertentu pada kedua buah motor seperti pada tabel III dengan durasi 100 ms.

TABEL III

\begin{tabular}{lcc}
\multicolumn{3}{c}{ NILAI PWM PADA SETIAP AKSI } \\
\hline \hline \multicolumn{1}{c}{ Aksi } & \multicolumn{2}{c}{ Nilai PWM } \\
& Motor Kiri & Motor Kanan \\
\hline Berhenti & 0 & 0 \\
Belok Kiri & 0 & 150 \\
Maju & 150 & 150 \\
Belok Kanan & 150 & 0 \\
Mundur & 150 & 150 \\
\hline \hline
\end{tabular}

Komponen ketiga adalah penentuan besaran reward. Reward adalah hadiah yang didapatkan robot saat selesai melakukan aksi. Nilai reward bisa berupa positif atau negatif. Adapun besaran reward seperti yang ditunjukan oleh persamaan (2).

$$
\text { Besaran Reward }=\{-3,1,4,4,1,-3\}
$$

Nilai pada masing - masing index pada persamaan (2) merupakan representasi kondisi pada setiap sensor yang aktif. Idealnya robot akan memiliki nilai reward yang besar saat robot berada di tengah garis lintasan dan apabila robot berada di pinggir garis lintasan maka nilai reward yang didapatkan akan cenderung kecil ataupun bernilai negatif.

Setelah menentukan komponen yang diperlukan, selanjutnya dibuatlah sistem kerja dari fase learning seperti pada gambar 4.

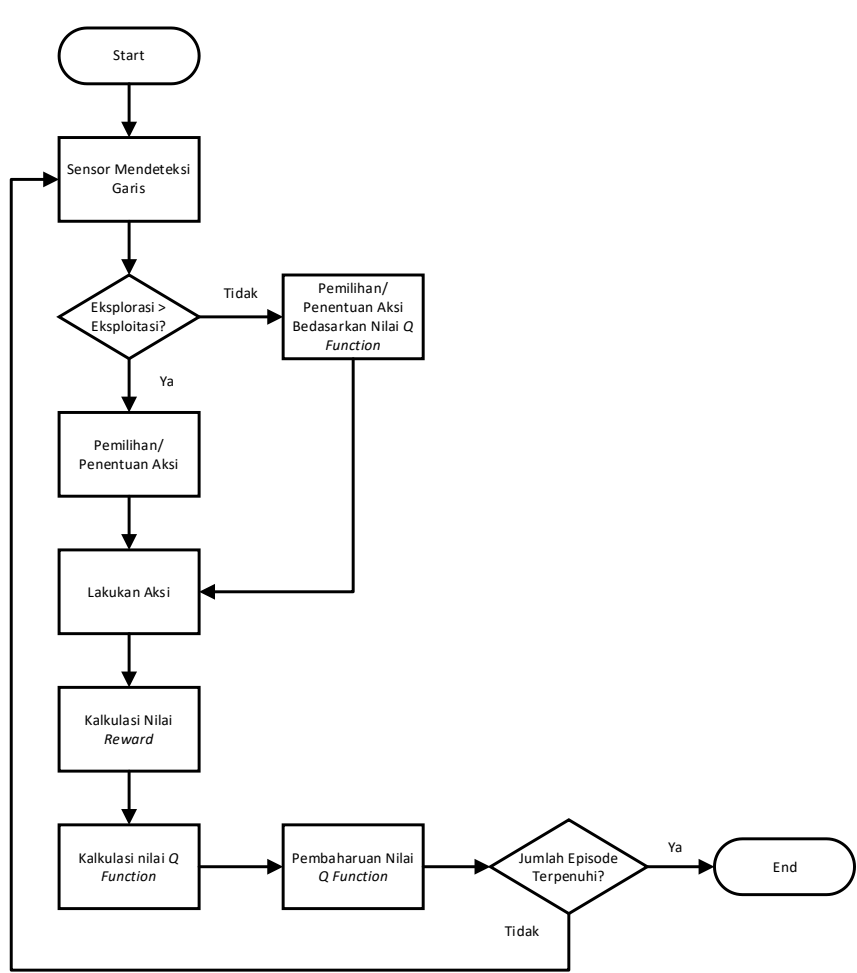

Gambar 4. Flowchart sistem kerja fase learning

Gambar 4 adalah flowchart sistem kerja fase learning, di mana tahapannya seperti berikut:

1) Pendeteksian garis lintasan untuk mendapatkan nilai state.

2) Melakukan perbandingan nilai antara eksplorasi dan eksploitasi.

3) Jika nilai ekploitasi lebih besar maka aksi yang diambil berdasarkan dari nilai $Q$ function yang tertinggi.

4) Jika nilai ekplorasi lebih besar maka robot memilih aksi acak.

5) Melakukan aksi dari penentuan aksi.

6) Kalkulasi nilai reward dari aksi yang telah dilakukan.

7) Kalkulasi nilai $Q$ function untuk memperbaharui nilai $Q$ function pada state yang terdeteksi.

\section{b. Penyimpanan Nilai Q Function}

Pada bagian ini merupakan proses penyimpanan nilai $Q$ function dari masing - masing state pada setiap aksi ke SD card yang memiliki tujuan untuk mempermudah dalam proses pengolahan data.

\section{c. Pengambilan Aksi Berdasarkan Nilai Maksimum Q Function}

Pada bagian ini, robot melakukan aksi berdasarkan nilai $Q$ function yang tertinggi. Hal ini bertujuan untuk proses pengujian pembuktian bahwa robot benar - benar bergerak berdasarkan aksi dengan nilai yang tertinggi. Proses bagian ini tidak akan memperbaharui nilai $Q$ function dan juga aksi yang dilakukan tidak akan mendapatkan reward. 


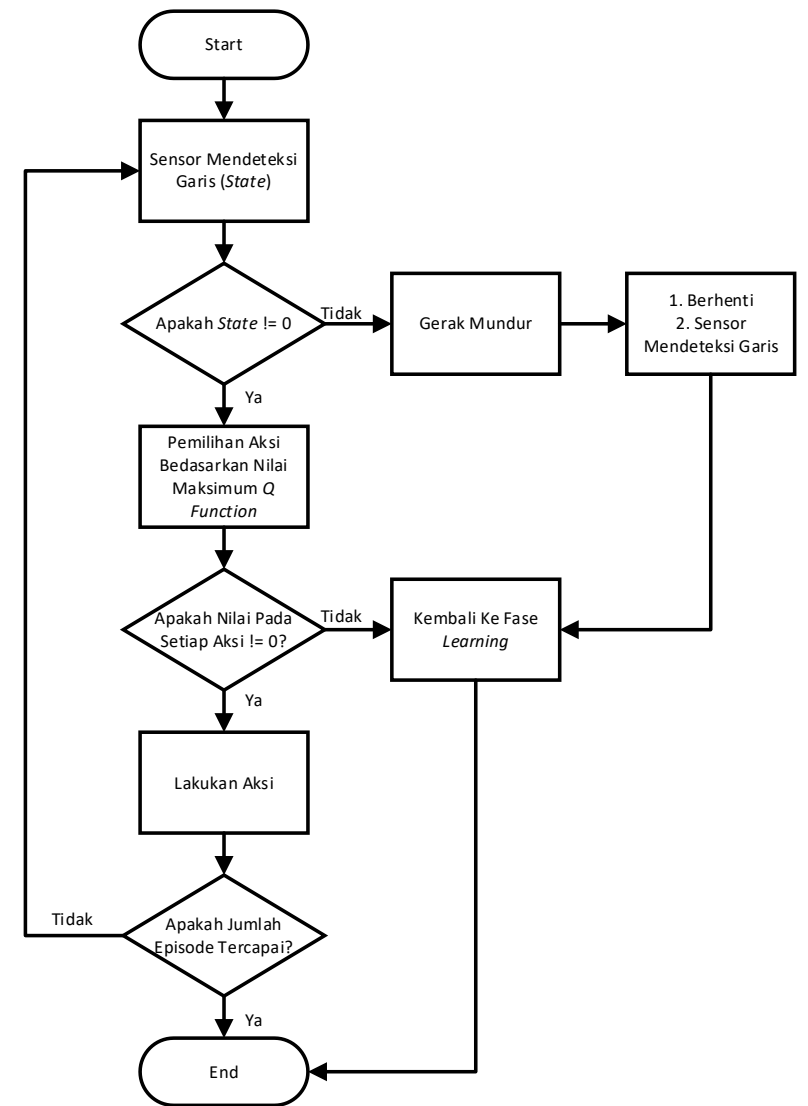

Gambar 5. Flowchart Sistem Kerja Pengambilan Aksi Berdasarkan Nilai Maksimum $Q$ Function

Gambar 5 adalah flowchart dari sistem kerja pengambilan aksi berdasarkan nilai maksimum $Q$ function di mana sistem kerja ini memiliki tahapan sebagai berikut:

1) Pendeteksian garis untuk mendapatkan state.

2) Pemeriksaan nilai state. Jika bernilai 0 maka diindikasikan bahwa robot keluar jalur lalu robot akan bergerak mundur sekali.

3) Pemilihan aksi berdasarkan nilai maksimum $Q$ function pada masing - masing kolom aksi. Jika semua aksi memiliki nilai 0 maka robot kembali ke fase learning.

4) Pengambilan aksi dari hasil pemilihan aksi pada tahap sebelumnya.

5) Pemeriksaan jumlah episode. Jika jumlah episode tercapai maka robot kembali ke fase learning. Banyaknya episode yang digunakan adalah 50 .

\section{HASIL DAN PEMBAHASAN}

\section{A. Hasil Fase Learning}

Fase learning pada penelitian ini dilakukan sebanyak 50 iterasi di mana setiap iterasinya robot melakukan perhitungan nilai $Q$ function dari tiap state yang terdeteksi sebanyak 50 kali. Alasan penggunaan 50 iterasi dikarenakan robot telah banyak mengalami perubahan nilai pada masing - masing state yang terdeteksi di setiap kolom aksinya.

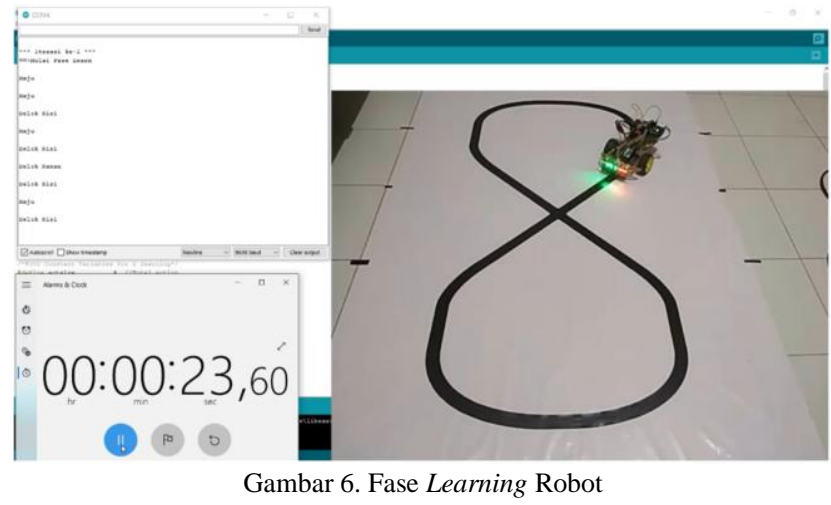

Gambar 6 adalah proses fase learning robot di mana robot melakukan pendeteksian garis lintasan untuk mendapatkan state selanjutnya melakukan aksi untuk mendapatkan reward dan melakukan kalkulasi nilai $Q$ function dari aksi yang telah dilakukan pada state yang terdeteksi. Nilai $Q$ function pada masing - masing state di setiap kolom aksi akan mengalami perubahan seiring robot melakukan aksi untuk mendapatkan reward. Perubahan nilai tersebut berupa nilai positif ataupun nilai negatif. Perubahaan nilai ini hanya terjadi pada state yang terdeteksi seperti pada tabel IV.

TABEL IV

KETERANGAN PERUBAHAN NILAI Q FUNCTION

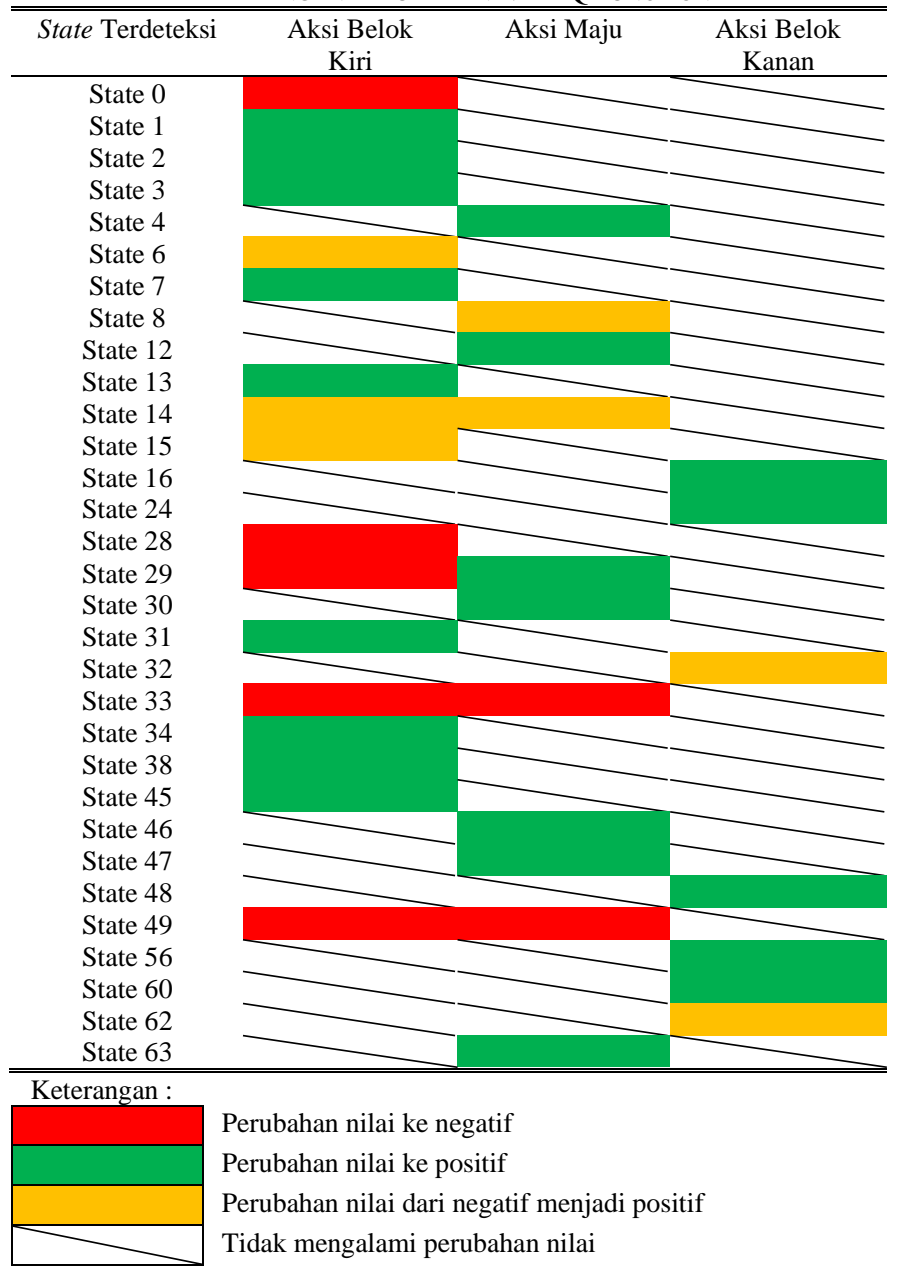


Untuk nilai yang didapatkan setelah 50 kali iterasi seperti pada tabel V.

TABEL V

NILAI Q FUNCTION SETELAH 50 KALI ITERASI

\begin{tabular}{|c|c|c|c|}
\hline State Tedeteksi & $\begin{array}{l}\text { Aksi Belok } \\
\text { Kiri }\end{array}$ & Aksi Maju & $\begin{array}{l}\text { Aksi Belok } \\
\text { Kanan }\end{array}$ \\
\hline 0 & -4.20 & 0 & 0 \\
\hline 1 & 39.15 & 0 & 0 \\
\hline 2 & 42.34 & 0 & 0 \\
\hline 3 & 40.88 & 0 & 0 \\
\hline 4 & 0 & 7.28 & 0 \\
\hline 6 & 42.71 & 0 & 0 \\
\hline 7 & 37.72 & 0 & 0 \\
\hline 8 & 0 & 38.09 & 0 \\
\hline 12 & 0 & 40.32 & 0 \\
\hline 13 & 37.34 & 0 & 0 \\
\hline 14 & 34.78 & 39.22 & 0 \\
\hline 15 & 40.07 & 0 & 0 \\
\hline 16 & 0 & 0 & 48.56 \\
\hline 24 & 0 & 0 & 40.91 \\
\hline 28 & -4.20 & 32.63 & 0 \\
\hline 29 & -4.20 & 35.82 & 0 \\
\hline 30 & 0 & 37.86 & 0 \\
\hline 31 & 42.17 & 0 & 0 \\
\hline 32 & 0 & 0 & 33.32 \\
\hline 33 & -4.20 & -4.20 & 0 \\
\hline 34 & 44.79 & 0 & 0 \\
\hline 38 & 36.70 & 0 & 0 \\
\hline 45 & 41.74 & 0 & 0 \\
\hline 46 & 0 & 40.67 & 0 \\
\hline 47 & 0 & 31.91 & 0 \\
\hline 48 & 0 & 0 & 43.13 \\
\hline 49 & -4.20 & -4.20 & 0 \\
\hline 56 & 0 & 0 & 38.63 \\
\hline 60 & 0 & 0 & 5.60 \\
\hline 62 & 0 & 0 & 42.22 \\
\hline 63 & 0 & 42.87 & 0 \\
\hline
\end{tabular}

\section{B. Pengujian Pengambilan Aksi Berdasarkan Nilai $Q$} Function

Pengujian ini dilakukan setelah fase learning selesai, dimana robot mengambil aksi berdasarkan nilai $Q$ function. Sama seperti fase learning, robot melakukan pendeteksian nilai state dan selanjutnya mengambil aksi. Akan tetapi dalam pengambilan aksi pada tahap pengujian berbeda dengan fase learning di mana pada tahapan pengujian aksi yang diambil adalah aksi dengan nilai yang paling tinggi.

Gambar 7 merupakan proses pengujian pengambilan aksi berdasarkan nilai $Q$ function. Pengujian ini bertujuan untuk melihat kualitas dari aksi dengan nilai tertinggi yang diambil oleh robot. Kualitas yang dimaksud adalah robot dapat bergerak tanpa keluar garis. Untuk parameter keberhasilannya sendiri yaitu:

1) Robot tidak keluar jalur.

2) Robot kembali ke fase learning jika semua aksi pada state terdeteksi $\leq 0$.

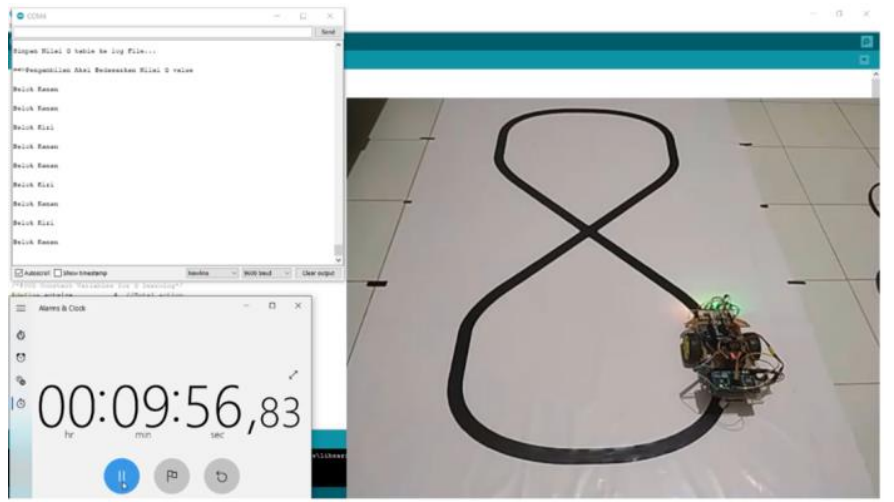

Gambar 7. Pengujian Pengambilan Aksi Berdasarkan Nilai $Q$ Function

Percobaan dilakukan sebanyak 5 kali di mana pengambilan data pengujian dilakukan pada iterasi 36 sampai dengan 50 dikarenakan robot telah banyak melakukan pengambilan data dan kalkulasi nilai $Q$ function. Adapun batas jumlah pengambilan aksi yang dilakukan yaitu sebanyak 50 kali. Hasil percobaan pengambilan aksi dapat dilihat pada tabel VI-X.

TABEL VI

Hasil PercobaAn Pertama

\begin{tabular}{cccc}
\hline \hline No. & Iterasi & $\begin{array}{c}\text { Jumlah } \\
\text { Pengambilan Aksi }\end{array}$ & Keterangan \\
\hline 1 & 36 & 50 & Berhasil \\
2 & 37 & 50 & Berhasil \\
3 & 38 & 9 & Berhasil \\
4 & 39 & 50 & Berhasil \\
5 & 40 & 50 & Berhasil \\
6 & 41 & 50 & Berhasil \\
7 & 42 & 50 & Berhasil \\
8 & 43 & 45 & Berhasil \\
9 & 44 & 50 & Berhasil \\
10 & 45 & 50 & Berhasil \\
11 & 46 & 50 & Berhasil \\
12 & 47 & 50 & Berhasil \\
13 & 48 & 50 & Berhasil \\
14 & 49 & 29 & Berhasil \\
15 & 50 & 50 & Berhasil \\
\hline \hline
\end{tabular}

TABEL VII

HASil PERCoBAan Kedua

\begin{tabular}{cccc}
\hline \hline No. & Iterasi & $\begin{array}{c}\text { Jumlah } \\
\text { Pengambilan Aksi }\end{array}$ & Keterangan \\
\hline 1 & 36 & 10 & Nilai $\leq 0$ \\
2 & 37 & 14 & Keluar Jalur \\
3 & 38 & 50 & Berhasil \\
4 & 39 & 22 & Berhasil \\
5 & 40 & 16 & Keluar Jalur \\
6 & 41 & 50 & Berhasil \\
7 & 42 & 34 & Berhasil \\
8 & 43 & 50 & Berhasil \\
9 & 44 & 5 & Keluar Jalur \\
10 & 45 & 0 & Berhasil \\
11 & 46 & 1 & Keluar Jalur \\
12 & 47 & 50 & Berhasil \\
13 & 48 & 37 & Nilai $\leq 0$ \\
14 & 49 & 1 & Keluar Jalur \\
15 & 50 & 50 & Berhasil \\
\hline \hline
\end{tabular}


TABEL VIII

Hasil PercobaAn Ketiga

\begin{tabular}{cccc}
\hline No. & Iterasi & $\begin{array}{c}\text { Jumlah } \\
\text { Pengambilan Aksi }\end{array}$ & Keterangan \\
\hline 1 & 36 & 50 & Berhasil \\
2 & 37 & 50 & Berhasil \\
3 & 38 & 50 & Berhasil \\
4 & 39 & 50 & Berhasil \\
5 & 40 & 50 & Berhasil \\
6 & 41 & 50 & Berhasil \\
7 & 42 & 50 & Berhasil \\
8 & 43 & 50 & Berhasil \\
9 & 44 & 50 & Berhasil \\
10 & 45 & 50 & Berhasil \\
11 & 46 & 17 & Nilai $\leq 0$ \\
12 & 47 & 50 & Berhasil \\
13 & 48 & 15 & Nilai $\leq 0$ \\
14 & 49 & 50 & Berhasil \\
15 & 50 & 50 & Berhasil \\
\hline \hline
\end{tabular}

TABEL IX

\begin{tabular}{cccc}
\multicolumn{4}{c}{ HASIL PERCOBAAN KEEMPAT } \\
\hline \hline No. & Iterasi & $\begin{array}{c}\text { Jumlah } \\
\text { Pengambilan Aksi }\end{array}$ & Keterangan \\
\hline 1 & 36 & 50 & Berhasil \\
2 & 37 & 50 & Berhasil \\
3 & 38 & 3 & Keluar Jalur \\
4 & 39 & 50 & Berhasil \\
5 & 40 & 50 & Berhasil \\
6 & 41 & 50 & Berhasil \\
7 & 42 & 8 & Keluar Jalur \\
8 & 43 & 50 & Berhasil \\
9 & 44 & 50 & Berhasil \\
10 & 45 & 50 & Berhasil \\
11 & 46 & 1 & Keluar Jalur \\
12 & 47 & 7 & Keluar Jalur \\
13 & 48 & 18 & Keluar Jalur \\
14 & 49 & 50 & Berhasil \\
15 & 50 & 50 & Berhasil \\
\hline \hline
\end{tabular}

TABEL $X$

Hasil PercobaAn Kelima

\begin{tabular}{cccc}
\hline \hline No. & Iterasi & $\begin{array}{c}\text { Jumlah } \\
\text { Pengambilan Aksi }\end{array}$ & Keterangan \\
\hline 1 & 36 & 50 & Berhasil \\
2 & 37 & 50 & Berhasil \\
3 & 38 & 5 & Berhasil \\
4 & 39 & 50 & Berhasil \\
5 & 40 & 50 & Berhasil \\
6 & 41 & 50 & Berhasil \\
7 & 42 & 50 & Berhasil \\
8 & 43 & 50 & Berhasil \\
9 & 44 & 50 & Berhasil \\
10 & 45 & 50 & Berhasil \\
11 & 46 & 50 & Berhasil \\
12 & 47 & 50 & Berhasil \\
13 & 48 & 50 & Berhasil \\
14 & 49 & 50 & Berhasil \\
15 & 50 & 50 & Berhasil \\
\hline \hline
\end{tabular}

Dari percobaan yang telah dilakukan, terdapat kegagalan pada percobaan 2 dan 4 . Pada percobaan 2 dapat dilihat pada Tabel VII, kegagalan terjadi pada iterasi 37, 40, 44, 46, dan 49. Sedangkan pada percobaan 4 dapat dilihat pada tabel IX, kegagalan terjadi pada iterasi $38,42,46,47$, dan 48 . Hal ini dikarenakan posisi robot yang cenderung berada di pinggir garis sehingga aksi yang dilakukan membuat robot keluar jalur.

Dalam 5 kali percobaan yang telah dilakukan maka didapatkan tingkat keberhasilan pada masing - masing percobaan ditunjukkan oleh Tabel XI.
TABEL XI

\begin{tabular}{ll}
\multicolumn{2}{c}{ TingKAT KEBERHASILAN } \\
\hline \hline $\begin{array}{l}\text { Percobaan } \\
\text { ke- }\end{array}$ & $\begin{array}{l}\text { Tingkat } \\
\text { Keberhasilan }\end{array}$ \\
\hline 1 & $100 \%$ \\
2 & $66.67 \%$ \\
3 & $100 \%$ \\
4 & $66.67 \%$ \\
5 & $100 \%$ \\
\hline Rata-rata & $86.67 \%$ \\
\hline \hline
\end{tabular}

\section{KeSIMPULAN}

Penelitian ini bertujuan agar robot dapat melakukan perbaikan kesalahan tanpa adanya campur tangan user. Dengan menggunakan algoritma $Q$ learning, robot melakukan kalkulasi nilai untuk setiap aksi yang telah dilakukan pada setiap state yang terbaca berdasarkan nilai reward yang didapatkan. Nilai reward bernilai negatif jika robot keluar jalur dan bernilai positif jika robot berada di dalam jalur. Nilai kalkulasi ini disebut sebagai nilai $Q$ function. Hasil pengujian pada percobaan 1, 3, dan 5 memiliki tingkat keberhasilan $100 \%$ dikarenakan robot mampu melaksanakan tugas dengan mengacu parameter keberhasilan yaitu robot tidak keluar jalur dan robot kembali ke fase learning apabila nilai $Q$ function $\leq 0$ pada setiap kolom aksi di state yang terdeteksi. Sedangkan pada percobaan 2 dan 4 memiliki tingkat keberhasilan $66.67 \%$ dikarenakan robot tidak mampu melaksanakan tugas dengan mengacu parameter keberhasilan. Sehingga nilai rata-rata keberhasilan sebesar $86.67 \%$. Penelitian ini masih perlu untuk dikembangkan terutamanya pemilihan mikrokontroler agar proses kalkulasi nilai $Q$ function berjalan cepat dan juga diperlukannya sebuah cara untuk meminimalisir getaran yang ditimbulkan saat robot melakukan aksi sehingga delay yang diperlukan untuk membuat sensor IR obstacle kembali stabil saat mendeteksi jalur menjadi kecil.

\section{REFERENSI}

[1] A.S. Romadhon and M. Fuad, "Perancangan Sistem Kontrol Gerakan Pada Robot Line Tracer," Ilm. Mikrotek, vol. 1, no. 1, pp. 53-58, 2013.

[2] David, "Kendali Logika Fuzzy Pada Robot Line Follower Line Follower Robot with Fuzzy Logic Control," Citec J., vol. 3, no. 1, pp. 15-25, 2016.

[3] A. Wajiansyah, S. Supriadi, S. Nur, and A. B. Wicaksono P, "Implementasi Fuzzy Logic Pada Robot Line Follower," J. Teknol. Inf. dan Ilmu Komput., vol. 5, no. 4, p. 395, 2018, doi: 10.25126/jtiik.201854747.

[4] M. Santo Gitakarma, "Perancangan Behavior-Based Robot Dengan Algoritma Fuzzy Q-Learning (Fql) Pada Sistem Navigasi Robot Otonom Beroda Dalam Medan Yang Tidak Terstruktur," JST (Jurnal Sains dan Teknol., vol. 2, no. 1, pp. 139-150, 2013, doi: 10.23887/jstundiksha.v1i1.1419.

[5] V. R. Cruz-Álvarez, E. Hidalgo-Peña, and H.-G. Acosta-Mesa, "A line follower robot implementation using Lego's Mindstorms Kit and QLearning," Acta Univ., vol. 22, pp. 113-118, 2012, doi: 10.15174/au.2012.350.

[6] S. Arifin, A. Tandy Hermawan, and Y. Kristian, "Pencarian Rute Line Follower Mobile Robot Pada Maze Dengan Metode Q Learning," J. Otomasi Kontrol dan Instrumentasi, vol. 8, no. 1, p. 55, 2016, doi: 10.5614/joki.2016.8.1.5. 